\title{
WASPADA TERHADAP MASALAH GIZI MELALUI PESAN PEDOMAN UMUM GIZI SEIMBANG (PUGS)
}

\author{
Haslina \\ Jurusan Teknologi Hasil Pertanian FTP dan Pt Universitas Semarang
}

\begin{abstract}
Life style change and behaviour has eaten evoke nutrient problem, that is problem more and nutrient less with various disease risk evoked. Efforts overcomings nutrient problem attunes alive wells and regular with consuming dish everyday with nutrient substance composition balance based on balance nutrient general guide message (PUGS). PUGS full 13 principal messages. It is important to know and practised by everybody at all groups and society layer for alive wells.
\end{abstract}

Keywords: lifestyle, nutrient problem, PUGS

\section{PENDAHULUAN}

Memasuki era globalisasi, Indonesia masih menghadapi masalah gizi ganda, yaitu masalah gizi kurang dan masalah gizi lebih dengan risiko penyakit yang ditimbulkan. Masalah gizi, meskipun sering berkaitan dengan masalah kekurangan pangan, pemecahannya tidak selalu berupa peningkatan produksi dan pengadaan pangan. Pada kasus tertentu, seperti dalam keadaan krisis (bencana kekeringan, perang, kekacauan sosial dan krisis ekonomi), masalah gizi muncul akibat masalah ketahanan pangan di tingkat rumah tangga, yaitu kemampuan rumah tangga memperoleh makanan untuk semua anggotanya. Menyadari hal itu, peningkatan status gizi masyarakat memerlukan kebijakan yang menjamin setiap anggota masyarakat untuk memperoleh makanan yang cukup jumlah dan mutunya. Dalam konteks ini masalah gizi tidak lagi menjadi masalah kesehatan tetapi juga masalah kemiskinan, pemerataan dan masalah kesempatan kerja.
Masalah gizi terdapat di masyarakat perdesaan dan perkotaan yang timbul sebagai akibat kekurangan atau kelebihan kandungan zat gizi dalam makanan. Kebiasaan mengkonsumsi makanan yang melebihi kecukupan gizi menimbulkan masalah gizi lebih yang terutama terjadi di kalangan masyarakat perkotaan. Dilain pihak empat masalah gizi kurang seperti gangguan akibat kekurangan yodium (GAKY), anemia gizi besi (AGB), kurang vitamin $A(K V A)$, kurang energi protein (KEP) masih tetap merupakan gangguan khususnya di pedesaan.

Dengan meningkatnya taraf hidup sebagian masyarakat yang tinggal baik di perkotaan maupun di pedesaan akan memberikan perubahan pada gaya hidup. Pemilihan makanan yang cenderung menyukai makanan siap santap akan menyebabkan kandungan gizi tidak seimbang. Rata-rata makanan jenis ini mengandung lemak dan garam tinggi, tetapi kandungan serat yang rendah. Disamping itu masih banyak masyarakat 
yang hidup di bawah garis kemiskinan di mana pemenuhan kebutuhan makanan kurang sehingga timbul masalah gizi kurang. Jadi masalah gizi yang timbul, baik masalah gizi lebih maupun masalah gizi kurang sebenarnya disebabkan oleh perilaku makan seseorang yang salah yaitu tidak adanya keseimbangan antara konsumsi gizi dengan kecukupan gizi. Untuk mengatasi masalah gizi, pemerintah menggalakkan program perbaikan gizi antara lain melalui peningkatan mutu konsumsi pangan dan penganekaragaman konsumsi pangan. Disamping itu sasaran program perbaikan gizi juga ditujukan untuk menanamkan perilaku gizi yang baik dan benar sesuai dengan Pedoman Umum Gizi Seimbang (Kodyat, 1997).

Menurt Truswell (1994), Pedoman Umum Gizi Seimbang (PUGS) diarahkan untuk dapat digunakan sebagai acuan perilaku gizi masyarakat, penyuluhan gizi dan penyusunan kebijakan gizi nasional. PUGS yang terdiri dari 13 pesan dasar, merupakan pedoman bagi setiap individu agar selalu mengkonsumsi makanan yang sehat, seimbang dan aman guna mempertahankan status gizi dan kesehatannya secara optimal.

\section{PEMBAHASAN}

\section{Perilaku Makan dan Gaya Hidup}

Berbagai penelitian menunjukkan bahwa perilaku makan yang salah akan menyebabkan masalah gizi dan perilaku makan tersebut dipengaruhi oleh aneka faktor sosial, ekonomi, budaya dan ketersediaan pangan. Analisis menggunakan data Susenas menunjukkan adanya kecenderungan perilaku konsumsi makanan jadi (termasuk minuman) yang semakin meningkat dari tahun ke tahun. Konsumsi makanan yang berasal dari terigu seperti roti, mie, kue kering dan konsumsi kue basah serta minuman es merupakan bagian dari makanan tradisional yang cenderung menurun (Surbakti dan Ahmat, 1997). Pola umum perilaku konsumen makanan jadi adalah semakin tinggi pendapatan semakin besar proporsi pengeluaran makanan jadi terhadap pengeluaran pangan total. Pada tahun 1996 sekitar seperlima pengeluaran pangan rumahtangga di perkotaan dialokasikan pada makanan jadi, sedangkan oleh rumah tangga di pedesaan sekitar seperdelapan dari pengeluaran pangan. $\mathrm{Di}$ kota-kota besar seperti Jakarta dan Yogyakarta pengeluaran untuk makanan jadi (termasuk fast food) lebih besar lagi yaitu seperempat dari total pengeluaran pangan. Kini makanan fast food telah menjadi bagian dari perilaku sebagian anak sekolah dan remaja di luar rumah di berbagai kota (Mudjianto, dkk 1997) dan diperkirakan cenderung akan semakin meningkat. Kelebihan dan daya tarik bisnis fast food ini terletak pada teknik promosi, hadiah, media campuran, penciptaan suasana, tempat dan pelayanan yang meningkatkan gengsi konsumen. Perubahan perilaku hidup atau gaya hidup sangat mempengaruhi pola makan masyarakat. Akibat perubahan perilaku masyarakat dalam gaya hidup yang kemudian berlanjut pada perubahan konsumsi makanan sehari-hari telah terbukti mempengaruhi prevalensi obesitas dan penyakit kardiovaskuler. Kegiatan fisik atau olahraga perlu dikembangkan secara terus menerus karena dapat membantu meningkatkan kesehatan masyarakat, di mana kegiatan fisik dan olahraga mempunyai tujuan ganda yaitu di satu sisi untuk peningkatan pengeluaran energi sebagai upaya penyeimbangan masukan dan pengeluaran energi dalam tubuh manusia, sedang dipihak lain merupakan upaya peningkatan kebugaran tubuh dan organ tubuh termasuk sistem kardiovaskuler.

Pemberian makanan yang cukup sangat penting untuk pertumbuhan dan perkembangan fisik, mental dan kecerdasan bayi. Dampak kekurangan makanan pada masa bayi akan diderita seumur hidup. Cara terbaik memberi makanan bayi adalah menyusui secara ekslusif. Pemberian Air Susu Ibu (ASI) ekslusif berarti bayi hanya minum ASI saja dan tidak diberikan makanan tambahan, air atau cairan lain kecuali obat-obatan dan vitamin. Berdasarkan studi IPB, Depkes dan WHO tahun 
2001 di kota Bogor diperoleh data dari 1102 bayi, yang diberi ASI ekslusif sampai umur 4 bulan hanya $22,8 \%$ (BKKBN, 2002).

\section{Masalah Gizi di Indonesia}

Memasuki era Pembangunan Jangka Panjang II (PJP II) Indonesia menghadapi masalah gizi yaitu masalah gizi lebih dan masalah gizi kurang dengan berbagai risiko penyakit yang menyertainya. Manifestasi gizi lebih adalah gemuk dan gemuk sekali pada kelompok masyarakat mampu. Salah makan yang sebagian atau seluruhnya dipengaruhi oleh gaya hidup seseorang, merupakan faktor risiko yang sumbangannya sangat tinggi terhadap munculnya penyakit-penyakit degeneratif. Makan lebih banyak dari kebutuhan, dan makan tidak seimbang dalam arti kebanyakan, faktor risiko dalam makanan dan kurangnya faktor proteksi dapat menyebabkan keadaan gizi lebih, yang pada gilirannya dapat membawa risiko masalah kesehatan (Budiyanto, 2002).

Di negara maju kelompok masyarakat usia 20-45 tahun dengan gizi lebih memiliki risiko relatif sebesar 5,9 kali untuk hipertensi dan 2,9 kali untuk diabetes mellitus, dibanding dengan kelompok gizi normal. Uji toleransi glukose penderita kelebihan berat badan hampir selalu menunjukkan ketidaknormalan yang merupakan indikator resistensi diabetes mellitus. Gizi lebih berisiko lebih besar terhadap penyakit kegemukan, diabetes, jantung, dan kanker (Martianto dan Roosita, 2003).

Gizi kurang membawa dampak bukan hanya pada kehidupan anak-anak yang masih muda, akan tetapi dapat terjadi pada semua golongan usia. Dampak buruk itu dapat termanifestasi dalam bentuk ringan atau berat. Anak-anak yang kekurangan gizi akan mengalami gangguan pertumbuhan fisik, mental dan intelektual. Gangguan tersebut akan menyebabkan tingginya angka kematian dan kesakitan serta berkurangnya potensi belajar, daya tahan tubuh dan produktivitas kerja. Dampak kekurangan gizi pada umur dini dimanifestasikan dalam bentuk fisik yang lebih kecil dengan tingkat produktivitas yang lebih rendah dan beberapa hasil analisis mengungkapkan terjadinya penyakit degeneratif pada masa dewasa yang justru merupakan umur produktif. Konsekuensi gangguan akibat kekurangan iodium (GAKI) adalah retardasi mental, gangguan perkembangan sistem syaraf, gangguan pertumbuhan fisik, kegagalan reproduksi dan kematian anak. Yang sangat mengkhawatirkan bagi pengembangan SDM adalah akibat negatif terhadap sistem syaraf pusat yang berdampak pada kecerdasan dan perkembangan sosial. Setiap penderita gondok akan mengelami defisit 10 IQ point, kretin 50 point dan GAKI lain $10 \mathrm{IQ}$ point di bawah normal. Dengan perkiraan sekitar 42 juta penduduk tinggal di daerah defisiensi yodium di mana 10 juta menderita gondok, 750-900 ribu menderita kretin endemik dan 3,5 juta menderita GAKI lainnya maka pada saat ini Indonesia telah mengalami defisit 132,5 - 140 juta IQ point akibat GAKI. Dengan kondisi yang sama, setiap tahun akan terus bertambah kehilangan $I Q$ point sebesar 10 juta point. Pengukuran GAKI yang lebih obyektif adalah berdasarkan kadar iodium dalam urin. Hampir semua zat iodium yang masuk ke dalam tubuh melalui makanan akhirnya dibuang melalui urin. Dikatakan normal, jika kadar iodium urin berkisar 100-200 mikrogram per liter. Nilai 50-90 mikrogram per liter menunjukkan GAKI ringan, 20-49 mikrogram per liter disebut GAKI sedang, dan jika di bawah 20 mikrogram per liter disebut GAKI berat (Martianto dan Raosita, 2003).

Anemia defisiensi besi dan anemia kurang besi biasanya sulit dibedakan karena gejalnya hampir sama, misalnya muka pucat, lelah, lesu dan karena gejala yang timbul tidak terlihat seperti penyakit yang membahayakan kehidupan. Akibat nyata anemia gizi terhadap kualitas SDM tergambar pada dampak meningkatnya angka kematian ibu (AKI) dan angka kematian bayi (AKB), menurunkan prestasi belajar anak sekolah serta menurunnya produktivitas para pekerja, yaitu $10-20 \%$ (Martianto dan Roosita, 2003). Anemia terjadi akibat kurangnya sel darah merah, 
suplai besi dalam jaringan kurang dan kombinasi antara keduanya. Fungsi utama besi dalam tubuh adalah untuk memproduksi hemoglobin yang dialirkan ke sel darah merah. Anemia antara lain dapat menyebabkan menurunnya kemampuan intelektual, produktivitas kerja menurun, meningkatnya angka kematian ibu dan anak, dan daya tahan tubuh terhadap infeksi menurun (Budiyanto, 2002).

\section{Pedoman Umum Gizi Seimbang (PUGS)}

Menyadari penyebab terjadinya masalah gizi karena perubahan pola pangan dan gaya hidup, maka disusun pedoman perilaku makan untuk bangsa Indonesia yang dikenal dengan Pedoman Umum Gizi Seimbang (PUGS). Disamping itu PUGS merupakan tindak lanjut dari Konferensi Gizi Internasional di Roma-Itali pada bulan Desember 1992. Hampir semua negara yang mengikuti konferensi tersebut menilai perlunya disusun Nutritional Guidelines atau Pedoman Umum Gizi Seimbang (PUGS) yang berguna untuk mencegah berbagai permasalahan gizi.

PUGS pada dasarnya merupakan suatu proses dinamisasi dan penjabaran secara operasional dari slogan empat sehat lima sempurna. Faktor-faktor yang diperhatikan sebagai dasar penyusunan PUGS adalah: a) masalah gizi yang dihadapi, b). keadaan sosial budaya, c). penemuan-penemuan mutakhir dibidang gizi dan d). slogan empat sehat lima sempurna (Ray, 1997).

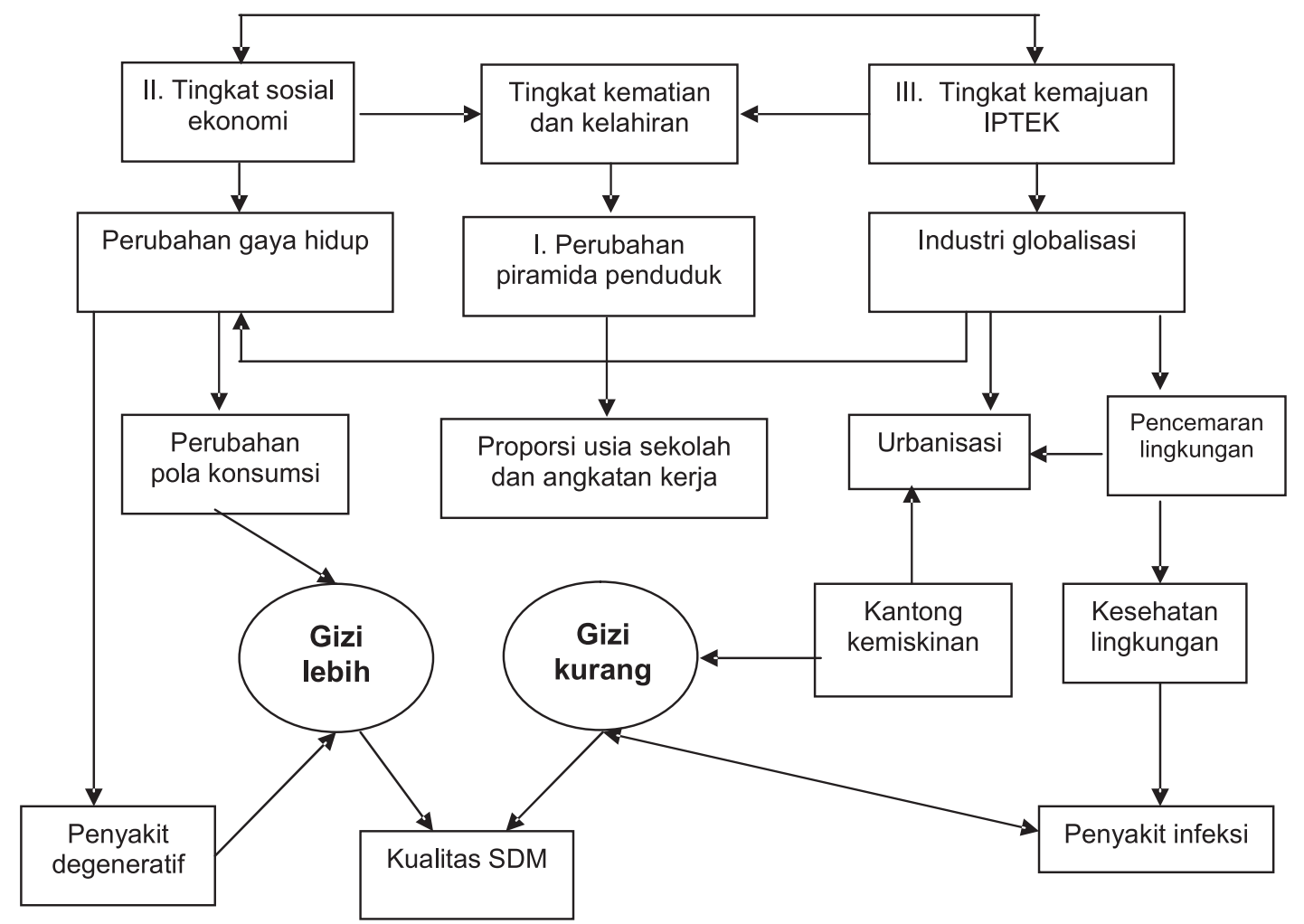

Gambar 1 Perubahan masalah gizi di Indonesia dan faktor penyebab (Baliwati dkk, 2004 dalam Soekirman, 1993) 
PUGS memuat 13 pesan dasar tentang perilaku makan yang diharapkan akan dapat mencegah permasalahan gizi dan menghindari terjadinya penyakit lain yang menyertainya (Depkes, 1994). 13 pesan tersebut adalah sebagai berikut :

1. Makanlah anekaragam makanan

2. Makanlah makanan untuk memenuhi kecukupan energi

3. Makanlah makanan sumber karbohidrat setengah dari kebutuhan energi

4. Batasi konsumsi lemak dan minyak sampai seperempat dari kecukupan energi

5. Gunakan garam beryodium

6. Makanlah makanan sumber zat besi

7. Berikan ASI saja pada bayi sampai umur 4 bulan

8. Biasakan makan pagi

9. Minumlah air bersih, aman yang cukup jumlahnya

10. Lakukan kegiatan fisik dan olahraga secara teratur

11. Hindari minum minuman beralkohol

12. Makanlah makanan yang aman bagi kesehatan

13. Bacalah label pada makanan yang dikemas

\section{SIMPULAN}

1. Perilaku makan dan perubahan gaya hidup telah menimbulkan masalah gizi.

2. Pesan Pedoman Umum Gizi Seimbang (PUGS) merupakan pedoman untuk berperilaku gizi yang baik dan benar, mengkonsumsi makanan yang sehat, seimbang dan aman guna mempertahankan status gizi dan kesehatan secara optimal.

\section{DAFTAR PUSTAKA}

BKKBN.2002. Upaya Mencapai Keluarga Sejahtera. http://www.bkkbn.go.id/ hqweb/pikas/2002/artikel170502.htm.

Baliwati Y.F, Khomsan A, Dwiwiani C.M. 2004. Penganatr Pangan dan Gizi. Penebar Swadaya, Jakarta.
Budiyanto M.A.K, 2002. Gizi dan Kesehatan. Penerbit Bayu Media dan UMM Press, Malang.

Departemen Kesehatan. 1995. Panduan 13 Pesan Dasar Gizi Seimbang. Departemen Kesehatan RI. Direktorat Jenderal Pembinaan Kesehatan Masyarakat Direktorat Bina Gizi Masyarakat. Departemen Kesehatan, Jakarta.

Kodyat, B. 1997. Overview Masalah dan Program Kesehatan dan Gizi Masyarakat di Indonesia. Makalah disampaikan pada Training Peningkatan Kemampuan Penelitian Bidang Kesehatan dan Gizi Masyarakat. Biotrop 18-30 Agustus 1997, Bogor.

Martianto P dan Roosita K. 2003. Masalah Gizi Mikro : Luasan, Penyebab dan Strategi Penanggulangannya. Kerjasama UNICEF, Institut Pertanian Bogor, Koalisi Fortifikasi Indonesia, IPB, Bogor.

Mudjianto D.Susanto, E.Luciasari dan Hermana.1997. Kebiasaan Makanan Golongan Remaja di Enam Kota Besar di Indonesia, Pusat Penelitian dan Pengembangan Gizi, Bogor.

Ray,N.K. 1997. Pemasaran Sosial PUGS dan ACMI. Pra Widyakarya Nasional Pangan dan Gizi VI, Jakarta.

Surbakti, S dan Ahmat A.1997. Arah Perkembangan Konsumsi Makanan dan Minuman dari 1987 - 1996. Pra Widya Karya Nasional Pangan dan Gizi VI, Jakarta.

Truswell, A.S. 1994. Dietary goals and guidelines: National and international perspective. dalam Shills, M.E, Olson, SA dan Shike, M. Modern Nutrition in Health and Disease. Philadelphia : Lea and Febryer. 